\title{
Circulating lysosomal enzymes and acute hepatic
} necrosis

\author{
CD GOVE, EN WARDLE, AND ROGER WILLIAMS \\ From the Liver Unit, King's College Hospital and Medical School, Denmark Hill, London SE5, UK
}

SUMMARY The activities of the lysosomal enzymes acid and neutral protease, $\mathrm{N}$-acetylglucosaminidase, and acid phosphatase were measured in the serum of patients with fulminant hepatic failure. Acid protease (cathepsin D) activity was increased about tenfold in patients who died and nearly fourfold in those who survived fulminant hepatic failure after paracetamol overdose, whereas activities were increased equally in patients with fulminant hepatic failure due to viral hepatitis whether or not they survived. A correlation was found between serum acid protease activity and prothrombin time, and the increase in cathepsin D activity was sustained over several days compared with aspartate aminotransferase, which showed a sharp early peak and then a fall. Circulating lysosomal proteases can damage other organs, and measurement of their activity may therefore be of added value in assessing prognosis in this condition.

The protection of cells from the activity of acid hydrolases by inclusion of the enzymes within lysosomes was first described by de Duve et al. in 1955. ${ }^{1}$ Since then it has been shown that rupture of the lysosomal membranes causes extensive damage to the cell contents and that in the advanced stages of hepatocellular necrosis these enzymes are released into the circulation. Thus Slater and Greenbaum ${ }^{2}$ found increased serum acid phosphatase activity 3-5 hours after the oral administration of the hepatotoxin carbon tetrachloride to rats. Liver ischaemia and hypoxia also increase the activity of plasma lysosomal enzymes, ${ }^{34}$ as does impaired perfusion of the splanchnic area due to any form of shock. ${ }^{5}$

The object of this study was further to assess changes in plasma lysosomal enzyme activity during the course of hepatic necrosis and their relationship to other indices of hepatic damage.

\section{Patients and methods}

Plasma samples $(6 \mathrm{ml}$ blood added to $1 \mathrm{ml} 3 \cdot 8 \%$ citrate) were collected on admission and daily thereafter from $\mathbf{4 0}$ patients with fulminant hepatic failure (FHF). Control samples were collected in an identical manner from $(a)$ normal laboratory staff and $(b)$ 40 ward patients with alcoholic cirrhosis. Plasma

Accepted for publication 25 June 1980 samples were prepared immediately after collection of blood and stored at $-20^{\circ} \mathrm{C}$ until used.

Plasma acid protease (cathepsin D) and plasma neutral protease activity were measured by incubating $0.5 \mathrm{ml}$ plasma for three hours with denatured bovine haemoglobin $(50 \mathrm{mg} / \mathrm{ml})$ in $0.1 \mathrm{M}$ acetate buffer, $\mathrm{pH} 3 \cdot 6$, and $0 \cdot 1 \mathrm{M}$ phosphate buffer, $\mathrm{pH} 7 \cdot 0$, respectively. The reaction was terminated by adding $0.5 \mathrm{M}$ trichloroacetic acid, and the tyrosine liberated by the protease activity was quantified at $660 \mathrm{~nm}$ using the blue colour produced by reaction with Folin-Ciocalteau reagent in alkaline solution. Acid and neutral protease activities were expressed as $\mu \mathrm{g}$ tyrosine released per ml plasma per hour after subtraction of unincubated blank values. Standardisation was achieved using solutions of known tyrosine content.

In most cases plasma $\mathrm{N}$-acetylglucosaminidase (NAG) and plasma acid phosphatase (AP) activities were also measured by fluorimetric techniques. NAG activity was assayed in $0.1 \mathrm{ml}$ plasma samples in $0.5 \mathrm{M}$ citrate buffer, $\mathrm{pH} 4.5$, incubated with $0.1 \mathrm{ml}$ of 4-methyl umbelliferone pyranoside $(0 \cdot 1 \mathrm{mg} / \mathrm{ml})$ at $37^{\circ} \mathrm{C}$ for 30 minutes. ${ }^{6}$ The reaction was terminated

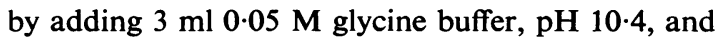
the fluorescence read at $450 \mathrm{~nm}$ using an excitation wavelength of $360 \mathrm{~nm}$. Acid phosphatase was assayed in a similar way using 4-methyl umbelliferone phosphate in $\mathbf{0 . 0 5} \mathrm{M}$ acetate buffer, $\mathrm{pH} 5 \cdot 0 .{ }^{\text {? }}$ 
Table 1 Mean $( \pm S D)$ circulating acid and neutral protease activity in patients with fulminant hepatic failure

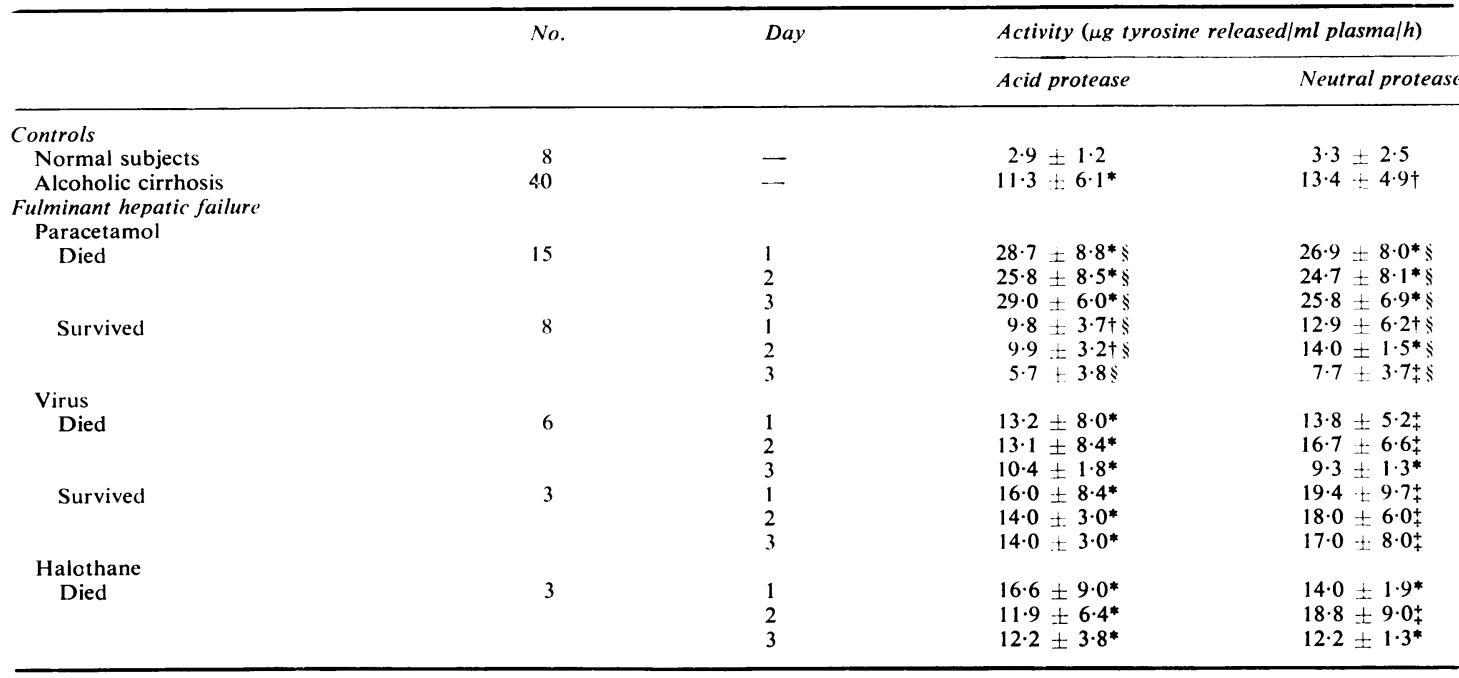

$*_{\mathrm{p}}<0.01 \mathrm{cf}$ normal control value.

†P $<0.02 \mathrm{cf}$ normal control value.

${ }_{+}^{+} \mathrm{P}<0.05$ cf normal control value.

$\$ P<0.005$ between survivors and non-survivors.

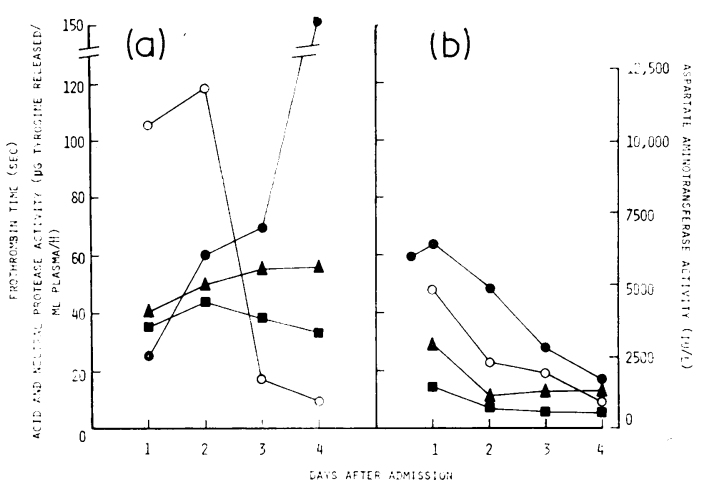

Fig. 1 Prothrombin time (O) and activities of aspartate aminotransferase $(\bigcirc)$, acid protease $(\mathbf{\Delta})$ and neutral protease $(\square)$ in plasma of $(a)$ one patient who died and (b) one patient who recovered after paracetamol self-poisoning.

Table 2 Prothrombin time and plasma cathepsin $D$ and aspartate aminotransferase activities measured serially in three patients with fulminant hepatic failure after paracetamol self-poisoning

\begin{tabular}{|c|c|c|c|c|c|c|}
\hline \multirow[t]{2}{*}{ Patient } & \multirow[t]{2}{*}{ Outcome } & & \multicolumn{4}{|c|}{ Time after admission (days) } \\
\hline & & & 1 & 2 & 3 & 4 \\
\hline \multirow[t]{3}{*}{1} & \multirow[t]{3}{*}{ Survived } & Cathepsin D ( $\mu$ g tyrosine $/ \mathrm{ml} / \mathrm{h})$ & 30 & 21 & 10 & 13 \\
\hline & & Prothrombin time $(\mathrm{sec})$ & 64 & 49 & 27 & 17 \\
\hline & & Aspartate aminotransferase (IU/I) & 4510 & 1760 & 500 & 350 \\
\hline \multirow[t]{3}{*}{2} & \multirow[t]{3}{*}{ Survived } & Cathepsin D ( $\mu \mathrm{g}$ tyrosine $/ \mathrm{ml} / \mathrm{h})$ & 14 & 6 & 3 & 2 \\
\hline & & Prothrombin time $(\mathrm{sec})$ & 95 & 95 & 48 & 20 \\
\hline & & Aspartate aminotransferase (IU/I) & 5000 & 3000 & 1000 & 200 \\
\hline \multirow[t]{3}{*}{3} & \multirow[t]{3}{*}{ Died } & Cathepsin D ( $\mu$ g tyrosine $/ \mathrm{ml} / \mathrm{h})$ & 16 & 16 & 36 & 28 \\
\hline & & Prothrombin time (sec) & 110 & 150 & 120 & 104 \\
\hline & & Aspartate aminotransferase (IU/l) & 5000 & 2000 & 800 & 410 \\
\hline
\end{tabular}

Fluorescence standardisation was achieved by use of an aqueous solution of quinine sulphate $(4 \mathrm{mg} / \mathrm{l})$.

\section{Results}

Acid and neutral protease activities in the serum of patients admitted after paracetamol self-poisoning were increased nearly tenfold on the day of admission in those patients who subsequently died but only fourfold in those patients who survived (Table 1). Those patients who died had persistently high protease activities for the 3-5 days before death, whereas activities decreased in those patients who recovered (Fig. 1, Table 1). Aspartate aminotransferase activity showed a sharp early peak and then fell over the next three days. No difference was found between survivors and non-survivors (Table 2). Serum acid and neutral protease activities were increased by the same amount in survivors and non-survivors of FHF 
Table 3 Mean ( $\pm S D$ ) circulating acid phosphatase and $N$-acetylglucosaminidase (NAG) activities in patients with fulminant hepatic failure

\begin{tabular}{|c|c|c|c|}
\hline & \multirow[t]{2}{*}{ No. } & \multicolumn{2}{|c|}{ Activity (mgMU/100 ml serum/h) } \\
\hline & & Acid phosphatase & $N A G$ \\
\hline \multicolumn{4}{|l|}{ Controls } \\
\hline $\begin{array}{l}\text { Normal } \\
\text { Alcoholic cirrhosis }\end{array}$ & $\begin{array}{r}6 \\
12\end{array}$ & $\begin{array}{l}2.0 \pm 0.6 \\
4.5 \pm 2.0\end{array}$ & $\begin{array}{l}2.0 \pm 1.0 \\
6.5 \pm 2.0 t\end{array}$ \\
\hline \multicolumn{4}{|l|}{$\begin{array}{l}\text { Fulminant hepatic failure } \\
\text { Paracetamol }\end{array}$} \\
\hline Died & 12 & $14.5 \pm 8.8 t$ & $6.9 \pm 3.0 \dagger$ \\
\hline \multicolumn{4}{|l|}{ Virus } \\
\hline Died & 6 & $14.7 \pm 3.8+$ & $8 \cdot 8 \pm 3 \cdot 2 \dagger$ \\
\hline Survived & 3 & $10.4 \pm 3.0_{+}^{+}$ & $10.6 \pm 3.0_{+}^{+}$ \\
\hline \multicolumn{4}{|l|}{ Halothane } \\
\hline Died & 3 & $4 \cdot 5 \pm 1 \cdot 2 \dagger$ & $4.4 \pm 0.7 \dagger$ \\
\hline
\end{tabular}

of viral aetiology. The activities were about threefold greater than in normal control subjects and were similar to those in patients with alcoholic cirrhosis or with halothane-induced hepatic necrosis (Table 1).

Acid phosphatase activity was increased in patients with hepatic necrosis due to paracetamol overdose and viral hepatitis, but there was no difference between patients who survived and those who died (Table 3 ). The increase in plasma NAG activity was similar to that of acid phosphatase but was higher in the survivors.

A correlation was found between acid protease (cathepsin D) activity and the prolongation of the prothrombin time $(r=0.79, P<0.001)$ (Fig. 2), while the correlation between neutral protease activity and the prolongation of the prothrombin time was poor $(r=0.42, P<0.01)$. The increase in the

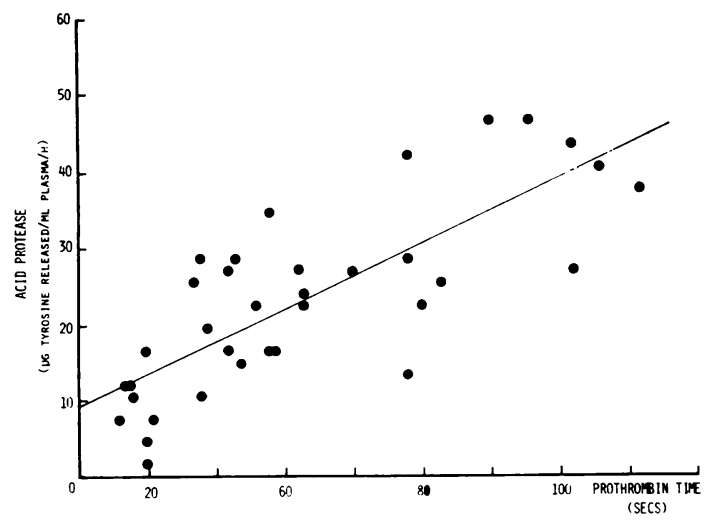

Fig. 2 Relationship between serum acid protease (cathepsin D) activity and prothrombin time $(r=0.79, \mathrm{P}<0.001)$. activity of cathepsin D on the day of admission (usually the third or fourth day after paracetamol ingestion) also showed a weak correlation with the serum aspartate aminotransferase activity measured simultaneously $(r=0.46, \mathrm{P}<0.01)$.

\section{Discussion}

Measurement of plasma acid protease activity could be of value in assessing the extent of hepatic necrosis in referral units, where patients may arrive late in the course of their illness. There is as yet no artificial substrate for cathepsin $D$, although the assay might be made more sensitive by fluorimetric estimation of the released tyrosine. ${ }^{8}$ In routine work, however, the very simple measurement of prothrombin time remains unchallenged as the indicator of hepatic damage.

The acid protease activities recorded (Table 1) suggest that there is more extensive hepatocellular necrosis after paracetamol poisoning than in cases of viral hepatitis. The acid phosphatase and NAG activities were raised equally in the two groups and no correlation was found between survival and activity of these two enzymes. In paracetamol necrosis plasma aminotransferases are of limited value in assessing prognosis ${ }^{9}$ because even quite small amounts of membrane damage can lead to leakage of cytosolic enzymes into the extracellular fluid.10 The peak of aminotransferase activity is early, but since increased protease activities tend to be sustained for several days their assay is of value when patients might reach a unit at a late stage. In the cases of fulminant hepatitis, however, it is recognised that aminotransferase activities are initially higher in those who die than in those who survive. ${ }^{11}$

Release of lysosomal enzymes into the plasma in FHF may add to the complications associated with the disease since such release in shock precedes renal failure, pulmonary damage, and myocardial depression. ${ }^{12} 13$ This idea is supported by the work of Toomasian, ${ }^{14}$ who showed in the rat that release of hepatic lysosomal enzymes is followed by damage to the lungs. It is also interesting to note that while only cathepsin D activity was measured in this study cathepsin $\mathrm{B}$ is also active at physiological $\mathrm{pH}$. Thromboplastins released at the same time as lysosomal enzymes may contribute to the onset of acute renal failure: when Ring-Larsen et al. ${ }^{15}$ produced hepatic failure in pigs by devascularisation and excluded the necrosing liver from the circulation renal failure did not follow.

We thank the Departments of Haematology and Chemical Pathology for measurement of prothrombin time and aminotransferase. 


\section{References}

${ }^{1}$ De Duve C, Pressman BC, Gianetto R, Wattiaux $R$, Appelrons F. Tissue fractionation studies: intracellular distribution patterns of enzymes in rat liver tissue. Biochem J 1955;60:604-17.

${ }^{2}$ Slater TF, Greenbaum AL. Changes in lysosomal enzymes in acute experimental liver injury. Biochem $J$ 1965;96: 484-91.

${ }^{3}$ Abraham R, Goldberg L, Grasso P. Hepatic response to lysosomal effects of hypoxia, neutral red and chloroquine. Nature 1967;215:194-6.

${ }^{4}$ Fredlund S, Ockerman PA, Vang JO. Acidosis and increased plasma levels of beta-D-glucosidase and betaD-galactosidase after hepatic inflow occlusion in the pig. Acta Chir Scand 1974;140:234-41.

s Baccino FM. Selected patterns of lysosomal response in hepatocytic injury. In: Slater TF, ed. Biochemical mechanisms of liver injury, Chap. 14. New York: Academic Press, 1978.

${ }^{6}$ Leaback DH, Walker PG. Studies on glucosaminidase: fluorimetric assay of $\mathrm{N}$-acetyl- $\beta$-glucosaminidase. Biochem $J 1961 ; 78: 151-6$.

${ }^{7}$ Robinson D, Willcox P. 4-methyl-umbelliferone phosphate as a substrate for lysosomal acid phosphatase. Biochim Biophys Acta 1969;191:183-6.
* Mednis A, Remold HG. A sensitive fluorimetric assay for determination of cathepsin D. Anal Biochem 1972;49: 134-8.

"James O, Lesna M, Robetts S, et al. Paracetamol overdosage and liver damage. Lancet 1975 ;ii:579-82.

${ }^{10}$ Schmidt E, Schmidt FW. Clinical enzymology. FEBS Lett 1976;62:E62-79.

${ }^{11}$ Sawhey VK, Knauer CM, Gregory PB. Rapid reduction of transaminase levels in fulminant hepatitis. $N$ Engl $J$ Med 1980;302:970.

${ }^{12}$ Lefer AM. The role of lysosomes in circulatory shock. Life Sci 1976;19:1803-9.

${ }^{13}$ Trewby PN, Warren R, Centini S, et al. Incidence and pathophysiology of pulmonary oedema in fulminant hepatic necrosis. Gastroenterology 1978;74:859-65.

1 Toomasian JM. Effects of hepatic autologous lysosomal enzymes in rat lungs. Surg Forum 1976;27:173-4.

${ }^{15}$ Ring-Larsen $H$, Tonnesen $H$, Holm $K$, Bentzen $M$, Christiansen LA. Renal and cerebral blood flow in experimental liver failure in the pig. Scand $J$ Gastroenterol 1979;14:91-6.

Requests for reprints to: Dr C Gove, Liver Unit, King's College Hospital Medical School, Denmark Hill, London SE5 8RX. 